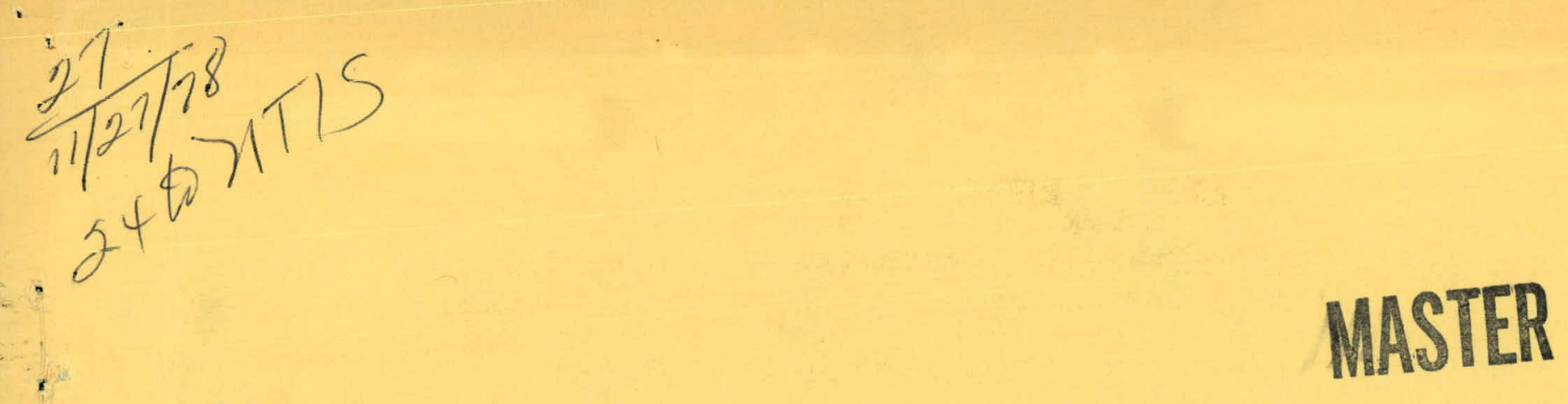

BDX-613-1890 (Rev.)

CHARACTERIZATION OF LOW DENSITY

RIGID URETHANE FOAM

By F. N. Larsen

Published October 1978

Topical Report

.T. R. Fender, Project Leader

Prepared for the United States Department of Energy Under Contract Number EY-76-C-04-0613. 


\section{DISCLAIMER}

This report was prepared as an account of work sponsored by an agency of the United States Government. Neither the United States Government nor any agency Thereof, nor any of their employees, makes any warranty, express or implied, or assumes any legal liability or responsibility for the accuracy, completeness, or usefulness of any information, apparatus, product, or process disclosed, or represents that its use would not infringe privately owned rights. Reference herein to any specific commercial product, process, or service by trade name, trademark, manufacturer, or otherwise does not necessarily constitute or imply its endorsement, recommendation, or favoring by the United States Government or any agency thereof. The views and opinions of authors expressed herein do not necessarily state or reflect those of the United States Government or any agency thereof. 


\section{DISCLAIMER}

Portions of this document may be illegible in electronic image products. Images are produced from the best available original document. 
This report was prepared as an account of work sponsored by the United States Government. Neither the United Statcs nor the United States Department of Energy, nor any of their employees, nor any $n f$ their contractors, subcontractors, or their employees, makes any warranty, express or implied, or assumes any legal liability or responsibility for the accuracy, completeness or usefulness of any information, apparatus, product or process disclosed, or represents that its use would not infringe privately owned rights.

Printed in the United States of America

Available From the National Technical Information Service, U.S. Department of Commerce, 5285 Port Royal Road, Springfield, Virginia 22161.

Price: Microfiche $\$ 3.00$

Paper Copy $\$ 4.00$ 
BDX-613-1890 (Rev.)

Distribution Category UC-25

CHARACTERIZATION OF LOW DENSITY

RIGID URETHANE FOAM

$\checkmark$ By F. N. Larsen

Published October 1978

Topical Report

J. R. Fender, Project Leader

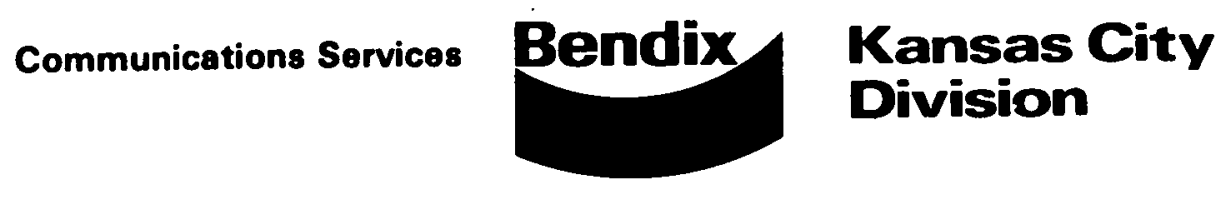




\title{
CHARACTERIZATION OF LOW DENSITY RIGID URETHANE FOAM
}

\author{
BDX-613-1890 (Rev.), UNCLASSIFIED Topical Report, Published \\ October 1978
}

Prepared by F. N. Larsen

The chemical and mechanical properties of a low density, rigid polyurethane foam material taken from a Joint Test Assembly (JTA) after 13 years of storage were measured. Chemical analyses confirmed the composition to be Bendix Rigifoam 6003-1.5, a pentaerythritol/ $\varepsilon$-caprolactone/tolyene diisocyanate polyurethane foam. Comparison of data from testing thermal and mechanical characteristics with data from a currently manufactured foam of identical composition indicates no degradation of properties had occurred. This information gives added confidence to the stockpile lifetime integrity of the Rigifoam 6003-2 foam system designated for use in other programs.

\section{$\mathrm{AB}-\mathrm{drb}$}

This report was prepared as an account of work sponsored by the United States Government. Neither the United States nor the United States Department of Energy, nor any of their employees. nor any of their contractors, subcontractors, or their employees. makes any warranty, express or implied or assumes any legal liability or responsibility for the accuracy. completeness or usefulness of any information, apparatus, product or process disclosed, or represents that its use would not infringe privately owned rights.
The Bendix Corporation Kansas City Division P. O. Box 1159 Kansas City, Missouri64141

A prime contractor with the United States Department of Energy under Contract Number EY-76-C-04-0613 
CONTENTS

Section
SUMMARY. . . . . . . . . . . . . . . . . . . . . . . . . . . . . . . . . . .




\section{LLUSTRAT IONS}

Figure

1

2

3

4

4

$\sqrt{2}+x^{2}$

$x^{2}$

Number

1
Thermomechanical Analysis of Aged Foam . . . Thermogravimetric Analysis of Rigifoams. . . Infrared Spectra of Rigifoams. . . . . . . . Storage Shear Modulus of Rigifoams . . . . .

\section{TABLES}

Page

\section{1}

12

13

16

Page

Formulation of Rigifoams $6003-1.5$ and 2. . .

8

Residual Amine Catalyst Content. . . . . . .

8

Mass Spectrometric Outgassing of Foam. . . .

9

Elemental, Ash, Moisture, and Halogen Analyses

10

Compressive Strength of Aged Foam. . . . . . .

15

Tensile Strength of Aged Foam. . . . . . . .

15

Processing Conditions for Rigifoam 6003-1.5. . 


\section{SUMMARY}

Information regarding the aging characteristics of materials is needed to guarantee stockpile lifetime integrity. Accelerated and long-term aging tests were performed on the polyurethane foam Rigifoam 6003-2. However, the availability of material as historical samples or from surveillance or test assemblies of considerable age was also very useful.

The project goals were to obtain a sample of Rigifoam 6003 that had been stored for some time, perform chemical and mechanical properties measurements, and compare properties to nominal foam properties to determine foam integrity and aging characteristics.

The material was taken from a stored Joint Test Assembly (JTA) unit. The foam was used for buoyancy. No other special properties were required for this application. The environment for the unit was not known but was assumed to have been ambient temperature and humidity. In the course of chemical testing, however, high moisture content, high ash content, and the presence of sodium and chlorine led to the conclusion that the unit had been exposed to sea water either from flight testing or buoyancy tests.

Chemical analysis confirmed the foam composition to be the Rigifoam 6003-1.5 formulation. Quantitative analysis for the amine catalyst ( $N$-methylmorpholine) at 1200 ppm conf1rmed that little or no loss of the amine had occurred after 13 years.

Dynamic shear modulus, tensile strength, and softening point test values indicated that little or no degradation of the low density, rigid polyurethane foam had occurred. Degradation would include embrittlement from oxidation or increased cross-linking and softening because of hydrolytic cleavage of ester or urethane groups.

The ability of this material to retain its physical and chemical properties after 13 years gives added confidence to the expected stockpile lifetime integrity of an identical foam system (without amine catalyst) to be used in other programs. 


\section{DISCUSSION}

\section{SCOPE AND PURPOSE}

Recent programs have required the use of low density, rigid polyurethane foam. The material selected for two of these programs is Rigifoam 6003-2, a thermally stable, $\varepsilon$-caprolactonebased polyester developed at Bendix Kansas City. ${ }^{1}$ With the current emphasis on extended stockpile life, personnel from the design agency (Lawrence Livermore Laboratory) were concerned about long-term aging of this material. Since no aging data was available, it was felt that examination of a piece of foam manufactured in the mid 1960s using the Rigifoam 6003-1.5 material could be helpful. A sample of the material was obtained, and a series of chemical and mechanical properties tests was performed. The compiled test data was evaluated for aging effects.

\section{PRIOR WORK}

No aging data was available on this material and very little mechanical or physical property data had been compiled. The original application used the buoyancy effect of a low density foam, so that no significant mechanical or physical properties were required.

\section{ACTIVITY}

Bendix records showed that the foam in an available JTA unit was manufactured in the period of 1963 to 1964. The history and use of the JTA unit was not determined. It was assumed that at least ambient temperature and humidity exposure occurred during the 13- to 14-year period. The parts were cleaned and examined. Two sections were photographed for further documentation, and the foam material was removed and sampled for testing.

\section{Description of Foam Material}

The foam used was a Bendix-developed material designated Rigifoam $6003-1.5$. It was foamed to a nominal density of $0.04 \mathrm{~g} / \mathrm{cm}^{3}$ $\left(2.5 \mathrm{lb} / \mathrm{ft}^{3}\right)$. The formulation for the foam is given in Table 1 , and the process is described in the Appendix. This material is essentially identical to the Rigifoam 6003-2 currently being used in several applications, except for the removal of amine catalyst (N-methylmorpholine), use of a different cell stabilizer, and addition of a surfactant in the 6003-2. ${ }^{2}$ The density is slightly higher $\left(0.05 \mathrm{~g} / \mathrm{cm}^{3}\right)$ in current applications requiring somewhat less water in the formulation. However, the materials are close enough in composition to allow correlation of many properties and to permit conclusions to be drawn regarding aging characteristics. 
A comprehensive series of tests was performed on samples of the aged material. These tests included thermal, chemical, mechanical, and physical properties measurements. Since no baseline data was available for this material, comparative data from current (1976-1977) activity on the Rigifoam 6003-2 was used for correlative purposes.

Residual N-methylmorpholine Content

A procedure using solvent extraction and gas chromatography for quantitative analysis was applied to three $1.5 \mathrm{~g}$ samples of the foam to determine the residual N-methylmorpholine amine catalyst content. Duplicate analyses were provided for each sample (Table 2 ).

The nominal value from the formulation is approximately 0.15 percent after allowing for carbon dioxide evolution. The experimental value of 0.14 percent is evidence that even after extended ambient exposure the amine catalyst is still present. This observation is also confirmed by testing the amine catalyzed 6003-2.5 foam. ${ }^{2}$ A nominal value of 0.12 percent is found after billet preparation, and this reduces to only 0.10 percent after aging 235 days at $80^{\circ} \mathrm{C}$ in an air circulating oven.

\section{Mass Spectrometry Outgassing}

A sample of the foam was analyzed for volatile components and outgassing using a mass spectrometer with a direct probe-solids inlet system. Table 3 gives the component outgassing as a function of temperature.

The outgassing up to $200^{\circ} \mathrm{C}$ does not contain degradation products to any extent but does give evidence of the presence of unreacted $\varepsilon$-caprolactone, the amine catalyst ( $N$-methylmorpholine), the organosilicone cell stabilizer, and diaminotoluene which originates when moisture reacts with tolylene disocyanate. These components confirm the foam composition to be Rigifoam 6003-1.5.

Elemental, Ash, and Moisture Analyses

The ash content was determined by placing a $10 \mathrm{~g}$ sample into a muffle furnace and raising the temperature to $650^{\circ} \mathrm{C}$ to burn off all carbonaceous materials leaving a noncombustible residue. The ash was then examined by emission spectroscopy for elemental composition. Total halogens were determined by oxygen combustion and coulometric titration. The ionic halogen content was determined by. water/ethanol extraction and coulometric titration (Table 4 ). 
Table 1. Formulation of Rigifoams 6003-1.5 and 2

\begin{tabular}{|c|c|c|}
\hline Component & $\begin{array}{l}6003-1.5 \\
\text { Parts by } \\
\text { Weight }\end{array}$ & $\begin{array}{l}6003-2 \\
\text { Parts by } \\
\text { Weight }\end{array}$ \\
\hline $\begin{array}{l}\text { Resin (R Component) } \\
\varepsilon-\text { caprolactone Polyester* } \\
\text { Cell Stabilizer } \\
\text { Water }\end{array}$ & $\begin{array}{r}100 \\
6 \\
12\end{array}$ & $\begin{array}{l}100 \\
2 \\
6.7\end{array}$ \\
\hline $\begin{array}{l}\text { Prepolymer ( } \mathrm{T} \text { Component) } \\
\text { Polyester Resin and Tolyene } \\
\text { Diisocyanate** }\end{array}$ & 363.2 & 275.2 \\
\hline $\begin{array}{c}\text { Catalyst (A Component) } \\
\text { N-methylmorpholine }\end{array}$ & 1 & 0 \\
\hline
\end{tabular}

*Hydroxyl number 600-620

$* * \mathrm{AE}=145$

Table 2. Residual Amine Catalyst Content

\begin{tabular}{|c|c|}
\hline $\begin{array}{l}\text { Sample } \\
\text { Number }\end{array}$ & $\begin{array}{l}\text { N-methylmorpholine } \\
\text { (Weight Percent) }\end{array}$ \\
\hline 1 & $\begin{array}{l}0.139 \\
0.133\end{array}$ \\
\hline $\begin{array}{l}2 \\
2\end{array}$ & $\begin{array}{l}0.134 \\
0.136\end{array}$ \\
\hline $\begin{array}{l}3 \\
3\end{array}$ & $\begin{array}{l}0.144 \\
0.142\end{array}$ \\
\hline Mean value, $\bar{X}$, for 3 samples & 0.138 \\
\hline Standard deviation & \pm 0.004 \\
\hline
\end{tabular}


Table 3. Mass Spectrometric Outgassing of Foam

Temperature

$\left({ }^{\circ} \mathrm{C}\right) \quad$ Components

28 to 45

$\mathrm{H}_{2} \mathrm{O}$ is the predominate species. There is trace $\mathrm{HCl}$ and even less indication of a hydrocarbon.

50 to 70

75

At approximately $60^{\circ} \mathrm{C}$ the $\mathrm{HCl}$ is the predominate species. The $\mathrm{H}_{2} \mathrm{O}$ has decreased in intensity as has the trace hydrocarbon.

85

$\mathrm{HCl}$ and $\varepsilon$-caprolactone

$\mathrm{HCl}, \varepsilon$-caprolactone, and $\mathrm{CH}_{3} \mathrm{Ph}\left(\mathrm{NH}_{2}\right)_{2}$

110

$\varepsilon$-caprolactone, $\mathrm{N}$-methylmorpholine, and $\mathrm{CH}_{3} \mathrm{Ph}\left(\mathrm{NH}_{2}\right)_{2}$

120

$\varepsilon$-caprolactone, $\mathrm{N}$-methylmorpholine, $\mathrm{CH}_{3} \mathrm{Ph}\left(\mathrm{NH}_{2}\right)_{2}$, and trace poly(dimethylsiloxane).

130

$\varepsilon$-caprolactone, $\mathrm{N}$-methylmorpholine, $\mathrm{CH}_{3} \mathrm{Ph}\left(\mathrm{NH}_{2}\right)_{2}$, and $\mathrm{CH}_{3} \mathrm{Ph}\left(\mathrm{NH}_{2}\right) \mathrm{NCO}$

140

$\mathrm{CH}_{3} \mathrm{Ph}\left(\mathrm{NH}_{2}\right)_{2}$ and $\mathrm{CH}_{3} \mathrm{Ph}\left(\mathrm{NH}_{2}\right)$ NCO are becoming intense. $\varepsilon$-caprolactone and $\mathrm{N}$-methylmorpholine are still present along with trace TDI and poly (dimethylsiloxane).

180

Basically the same as $140^{\circ} \mathrm{C}$. The $\varepsilon$-caprolactone and $\mathrm{N}$-methylmorpholine are becoming trace.

200

The $\varepsilon$-caprolactone and $\mathrm{N}$-methylmorpholine are no longer detectable.

It was apparent that the. JTA material had been exposed to sea water, perhaps to test buoyancy effects or for flight testing. The high magnesium to calcium content suggested natural sea water. Some corrosion also tended to confirm exposure to salt water. The ionic versus total halogen content probably was due to variation of salt (inhomogeniety) in the foam material used for the individual tests. The closeness of hydrogen and nitrogen contents to the 6003-2 foam helped confirm the composition.

Of course, all the test data must be tempered by the fact that this foam material was relatively high in moisture content and salt content compared to normal foam systems. 
Table 4. Elemental, Ash, Moisture, and Halogen Analyses

\begin{tabular}{lcc}
\hline & $\begin{array}{l}\text { JTA } \\
\text { Rigifoam } \\
6003-1.5 \\
\text { (Weight/Percent) }\end{array}$ & $\begin{array}{l}\text { Rigifoam } \\
6003-2 \\
\text { (Weight/Percent) }\end{array}$ \\
\hline Component & $57.3 * *$ & 59.5 \\
Hydrogen & $6.1 * *$ & 6.0 \\
Nitrogen & $9.9 * *$ & 10.4 \\
Water* & 3.28 & 1.0 \\
Total Halogens & 5.27 & $<0.001$ \\
Ionic Halogens & 1.08 & $<0.001$ \\
Ash & 14.3 & $<0.1$ \\
\hline$*$ At 29 percent relative humidity \\
$* * V a l u e s$ corrected for ash content \\
$\begin{array}{l}\text { Ash analysis for the } 6003-1.5 \text { only in ppm was } \\
40 \text { calcium, } \\
\text { with a major component of sodium. }\end{array}$
\end{tabular}

Thermal and Infrared Analyses

Thermal Analysis

Thermomechanical analysis (TMA) with an expansion probe and $1 \mathrm{~g}$ load produced a profile showing a definite transition at $50^{\circ}$ to $60^{\circ} \mathrm{C}$ and a softening point at $150^{\circ}$ to $175^{\circ} \mathrm{C}$. These values were in complete agreement with the profile and values for the 6003-2 material (Figure 1).

Thermogravimetric analysis (TGA) of the foam material in a nitrogen atmosphere showed a 3 percent weight loss up to $200^{\circ} \mathrm{C}$ (water) and the onset of thermal degradation at $230^{\circ}$ to $250^{\circ} \mathrm{C}$. A 22 percent residue was left after $500^{\circ} \mathrm{C}$, reflecting the high salt content. The water loss and degradation temperature were consistent with the TGA profile for 6003-2 (Figure 2). 


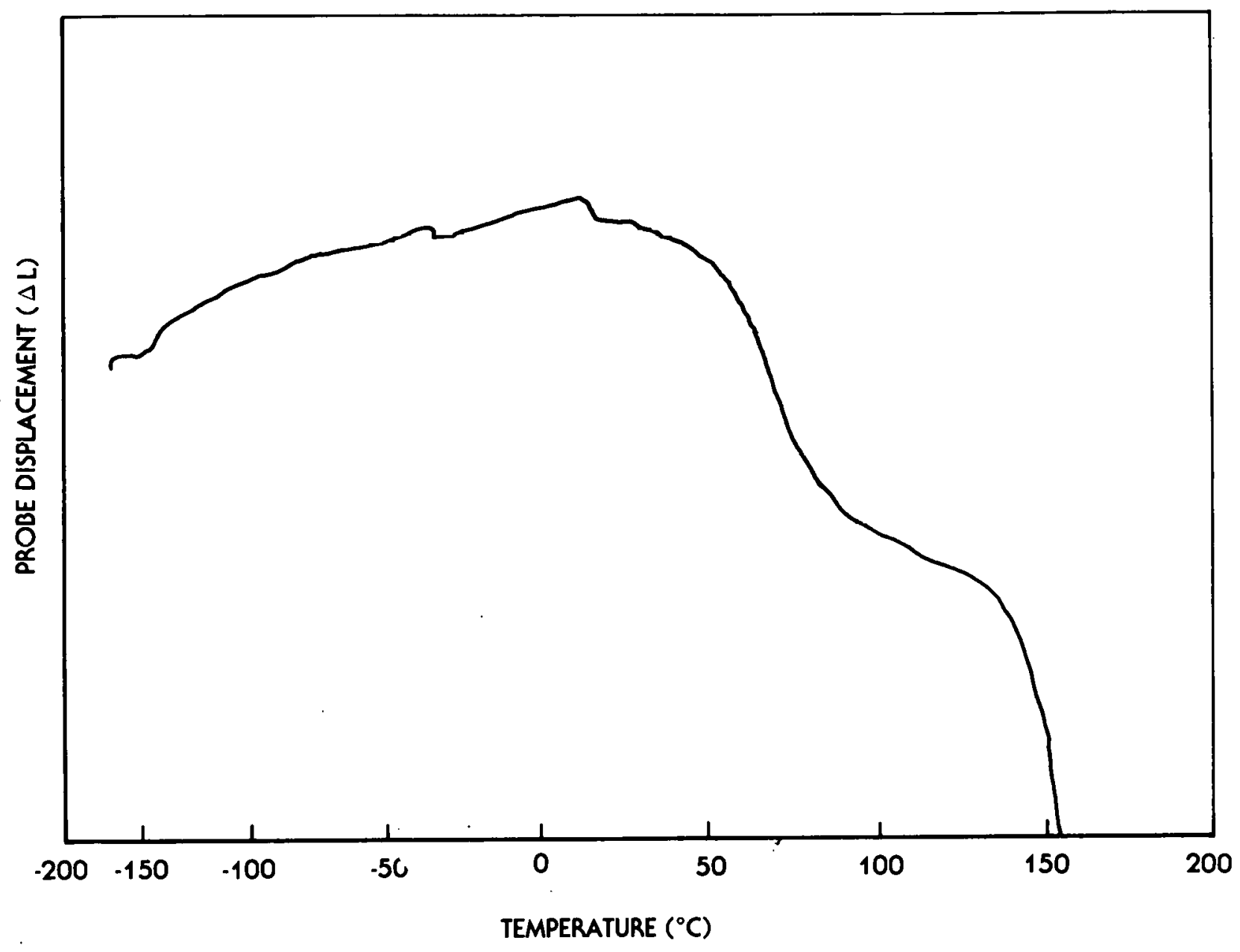

Figure 1. Thermomechanical Analysis of Aged Foam

Infrared Analysis

Infrared spectra (IR) of the foams prepared as $\mathrm{KBr}$ pellets were obtained and comparisons to the IR spectra of 6003-2, a CPR 1057 (polyether), and a CPR 1024 (polyester) foam gave positive identification that it was an $\varepsilon$-caprolactone/pentaerythritol/TDI type foam material. The two spectra for $6003-1.5$ and $6003-2$ are given in Figure 3. 


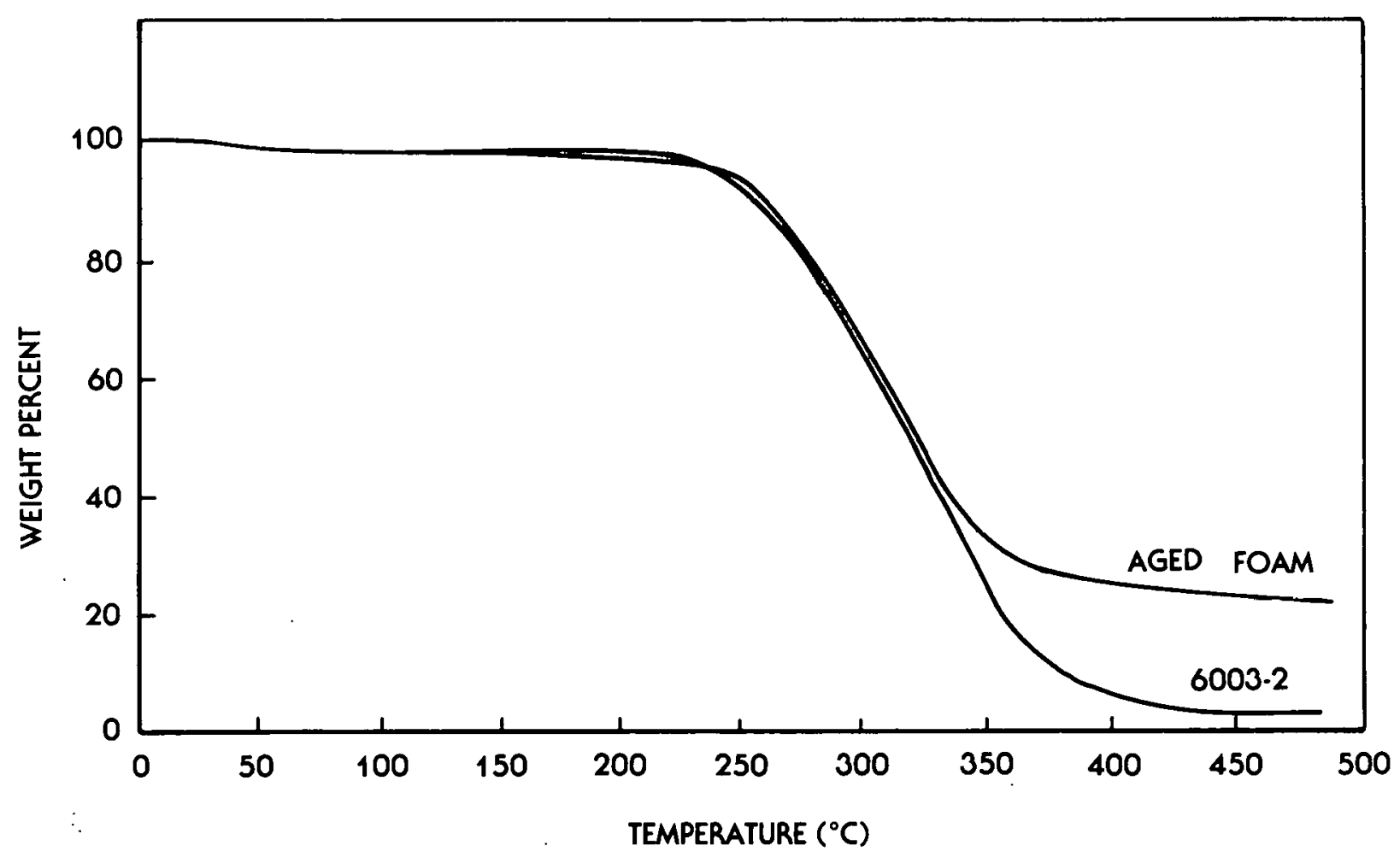

Figure 2. Thermogravimetric Analysis of Rigifoams

\section{Mechanical Properties}

Tensile and Compressive Strength

Cylindrical foam specimens $\left(25 \mathrm{~mm}^{2}\right.$ by $12.5 \mathrm{~mm}$ ) were used to determine butt tensile and compressive strengths. Normally, 25-mm-thick specimens are used for these tests, but the aged foam material did not have an adequate $25 \mathrm{~mm}$ thickness for sampling. The butt tensile specimens were bonded to the aluminum fixtures with epoxy resin. The test data are shown in Tables 5 and 6.

It was not possible to make any definitive statements about changes with aging for the mechanical properties of compressive and tensile strength since no zero time data was available for comparison. Tensile and compressive strengths of low density rigid polyurethane foams are highly dependent upon density, molding versus free rise foaming, and other variables. ${ }^{3}$ Consequently, comparison to the 6003-2 foam is not valid. However, a general observation was that the tensile strength was nominal for this 

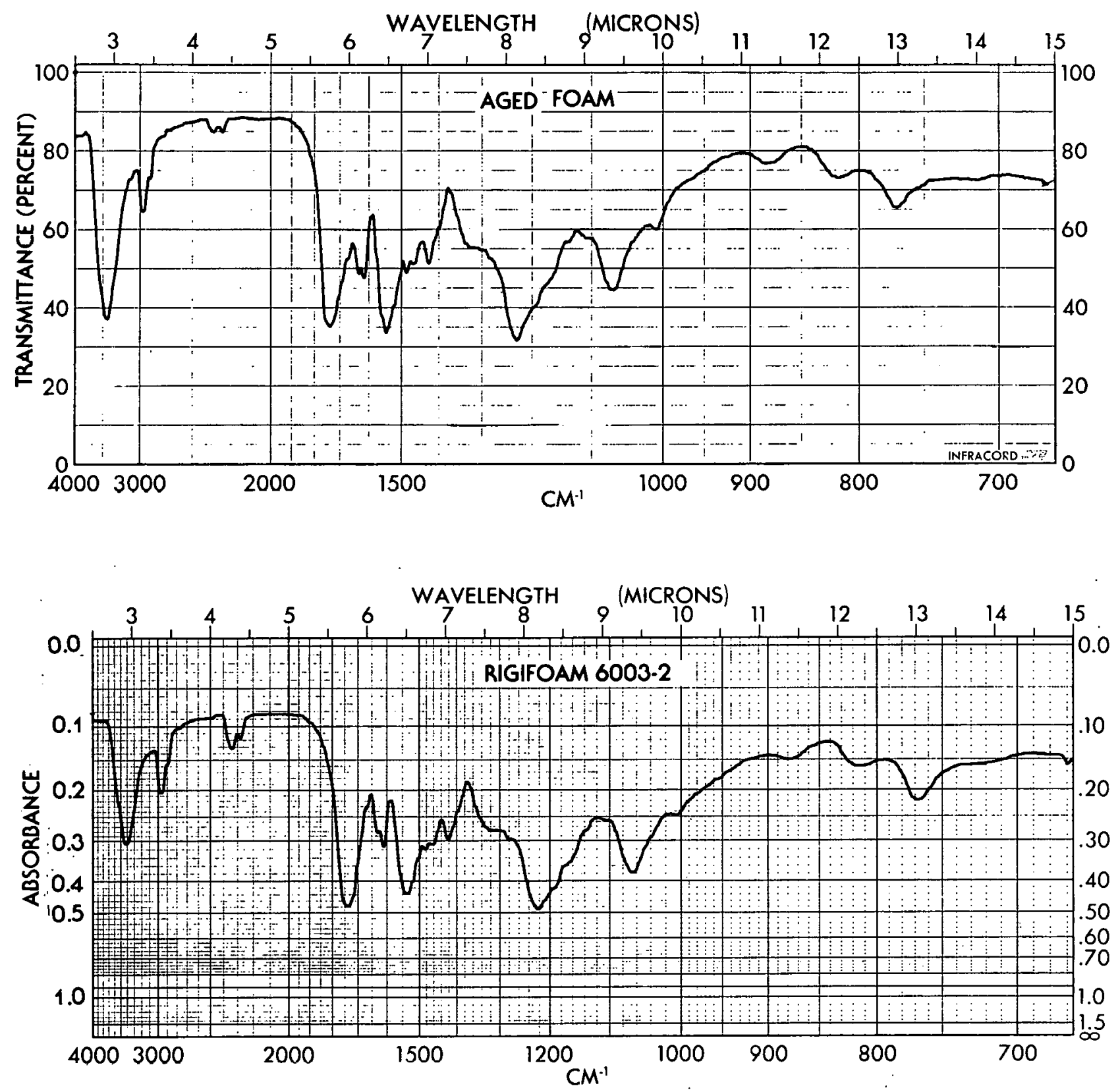

Figure 3: Infrared Spectra of Rigifoams 
range of density $\left(0.05 \pm 0.1 \mathrm{~g} / \mathrm{cm}^{3}\right)$ but that the compressive strength appeared to be somewhat low. This could be explained by the presence of the high water and salt content behaving as an internal plasticization.

Dynamic Shear Modulus

Specimens of foam ( 12.7 by 38.1 by $3.17 \mathrm{~mm}$ ) were prepared and the dynamic shear modulus was determined as a function of temperature $\left(-120^{\circ}\right.$ to $\left.160^{\circ} \mathrm{C}\right)$. The densities of the two specimens were 0.056 and $0.058 \mathrm{~g} / \mathrm{cm}^{3}$. Figure 4 illustrates the storage shear modulus for two sample runs (reproducibility) and a comparative curve for 6003-2 material. The storage shear moduli for the two materials are quite similar, and it can be reasonably assumed that no significant loss in this property of the foam has occurred.

\section{ACCOMPLISHMENTS}

The chemical, thermal, and mechanical properties of a low density foam material have been determined. The foam was recovered after 13 years of storage. A comparison of data taken from a similar, currently manufactured foam gave sufficient correlation to verify that no degradation or change in properties had occurred even though the aged foam had been exposed to salt water and contained some residual water and sodium chloride.

Information obtained supported long-term aging and hydrolytic stability studies. The low density rigid foam material, Rigifoam 6003-2, will meet stockpile lifetime requirements of new projects. 
Table 5. Compressive Strength of Aged Foam

\begin{tabular}{clllll}
\hline & $\begin{array}{l}\text { Compressive } \\
\text { Specimen } \\
\text { Number }\end{array}$ & $\begin{array}{l}\text { Modulus } \\
(\mathrm{MPa})(\mathrm{psi})\end{array}$ & \begin{tabular}{l} 
Compressive Strength \\
\cline { 4 - 6 }$(\mathrm{kPa})(\mathrm{psi})$
\end{tabular} & $\begin{array}{l}\text { 20 Percent } \\
(\mathrm{kPa})\end{array}$ \\
\hline 1 & $1.24(180)$ & $86.9(12.6)$ & 107 & $(15.5)$ \\
2 & $1.22(176)$ & $84.1(12.2)$ & 98.6 & $(14.3)$ \\
3 & $1.27(185)$ & $79.2(11.5)$ & 89.6 & $(13.0)$ \\
4 & $1.09(159)$ & $82.7(12.0)$ & 103 & $(14.9)$ \\
Average & $1.20(175)$ & $83.4(12.1)$ & 99.6 & $(14.4)$ \\
\hline
\end{tabular}

Table 6. Tensile Strength of Aged Foam

\begin{tabular}{llll}
\hline $\begin{array}{l}\text { Specimen } \\
\text { Number }\end{array}$ & $\begin{array}{l}\text { Tensile } \\
\text { Modulus } \\
\text { (MPa) (psi) }\end{array}$ & $\begin{array}{l}\text { Ultimate } \\
\text { Tensile Strength } \\
(\mathrm{kPa})(\mathrm{psi})\end{array}$ & $\begin{array}{l}\text { Ultimate } \\
\text { Tensile Strain } \\
\text { (Percent) }\end{array}$ \\
\hline 1 & $2.99(434)$ & $330(48)$ & 17.6 \\
2 & $3.12(453)$ & $290(43)$ & 13.3 \\
3 & $2.52(365)$ & $324(47)$ & 17.8 \\
4 & $3.33(484)$ & $324(47)$ & $12 \ldots 8$ \\
Average & $2.99(434)$ & $317(46)$ & 15.4 \\
\hline
\end{tabular}




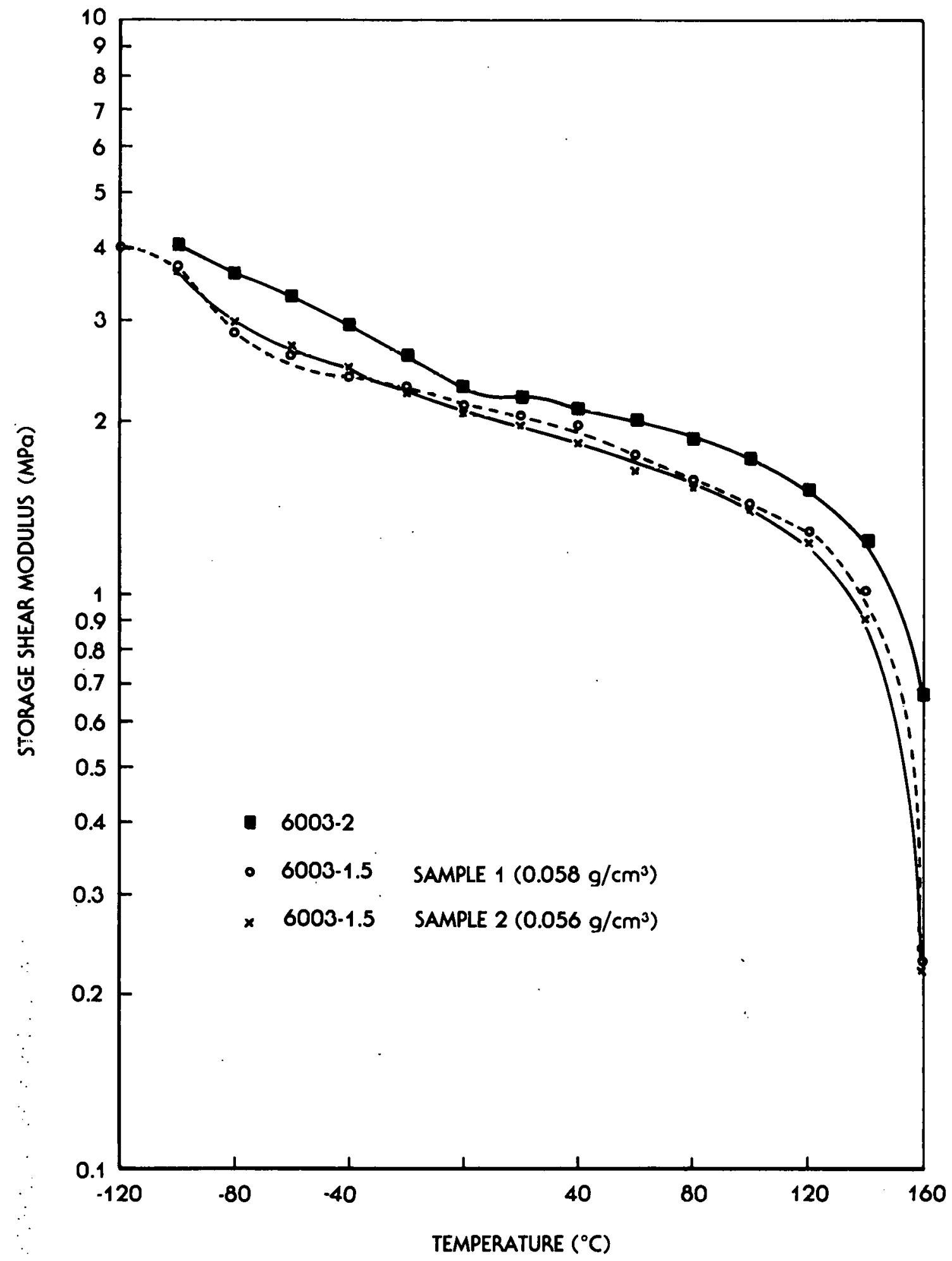

Figure 4. Storage Shear Modulus of Rigifoams 


\section{REFERENCES}

${ }^{1}$ C. H. Smith, Industrial and Engineering Chemistry, Products Research and Development, Volume 2, March, 1963, p 27.

${ }^{2} \mathrm{~J}$. R. Fender, Material Evaluation of Polyurethane Foam, $0.05 \mathrm{~g} / \mathrm{cm}^{3}$ Density ('Topical). UNCLASSIFIED. Bendix Kansas City: BDX-613-1836 (Rev.), April, 1978 (Available From NTIS).

${ }^{3}$ S. L. DeGisi and T. E Neet, Journal of Applied Polymer Science, Volume 20, 1976, p 2011. 
Appendix

PROCESS PROCEDURE

All components must be at room temperature. Place mold in oven at $57^{\circ} \mathrm{C} \pm 3^{\circ} \mathrm{C}$. Weigh $\mathrm{R}$ component into plastic coated $226 \mathrm{~g}$ drinking cup to nearest $0.1 \mathrm{~g}$ and add catalyst dropwise from furnished dropper. Remove cup from balance and mix unt1l homogeneous with spatula. Replace cup on balance and weigh in $\mathrm{T}$ component to nearest $0.1 \mathrm{~g}$. Immediately remove mold from oven at $57^{\circ} \pm 3^{\circ} \mathrm{C}$. Mix components in cup for 20 to 30 seconds with a $38 \mathrm{~mm}$ mixing blade driven with a high speed air stirrer. Pour $84 \mathrm{~g}$ of $\mathrm{mix}$ into mold and seal vent holes. Allow foam to gel 10 minutes in mold and then place mold in a $149^{\circ} \pm 3^{\circ} \mathrm{C}$ oven for 2 hours \pm 5 minutes. Remove mold from oven and allow to cool to room temperature before removing part from mold.

Table A-1. Processing Conditions for Rigifoam 6003-1.5

\begin{tabular}{ll}
\hline Component & Amount \\
\hline R Component & $29.5 \mathrm{~g}$ \\
T Component & $90.8 \mathrm{~g}$ \\
A Component & 10 Drops \\
Mix Time & 15 to 20 Seconds \\
Gel Time & $10 \mathrm{Minutes}$ \\
Mold Preheat & $57^{\circ} \pm 3^{\circ} \mathrm{C}$ \\
Cure Time & $2 \mathrm{Hours}_{5}$ \\
Cure Temperature & $149^{\circ} \pm 5^{\circ} \mathrm{C}$ \\
Mix Blade & $38 \mathrm{~mm} \mathrm{Diameter}$ \\
Mix Motor & $\mathrm{High} \mathrm{Speed} \mathrm{Air} \mathrm{Stirrer}$ \\
Finished Part Weight & $77 \pm 2 \mathrm{~g}^{2}$ \\
Volume of Part & $1875 \mathrm{~cm}^{3}$
\end{tabular}


R. Bulcock, ERDA-KCAO

V. C. Vespe, ERDA-ALO

F. W. DuBois, LASL

M. Matuszak, LASL

W. E. Cady, LLL

K. Ernst, LLL

H. G. Hammon, LLL

W. S. Inouye/P. M. Naillon, LLL

C. V. Johnson, I I I, LLL

H. Leider, LLL

J. H. Moyer/L. M. McGrew, LLL

D. L. Seaton, LLL

P. B. Rand, SLA

K. B. Wischmann, SLA

H. R. Sheppard, SLL

W. E. Tewes/H. O. Whitehead, Y-12

A. K. Zava, $\mathrm{Y}-12$

J. E. Long, D/531, 1B46

H. T. Barnes, D/554, BD50

L. Stratton, D/554, 2C44

R. P. Frohmberg, D/800, 2 A39

S. L. DeGisi, D/814, 2C43

W. H. Deterding, D/814, 2C 43

F. N. Larsen, D/814, XD43

T. E. Neet, D/814, XD43

C. H. Smith, Jr., D/814, XD43

G. L. MacCurdy, D/816, SC-3

V. E. Alley, D/818, 2A31

J. E. Anderson, D/818, 2A32

J. R. Fender, D/818, $2 A 31$

R. W. Klee, D/818, 2A31

R. E. Kessler, D/865, 2C40 


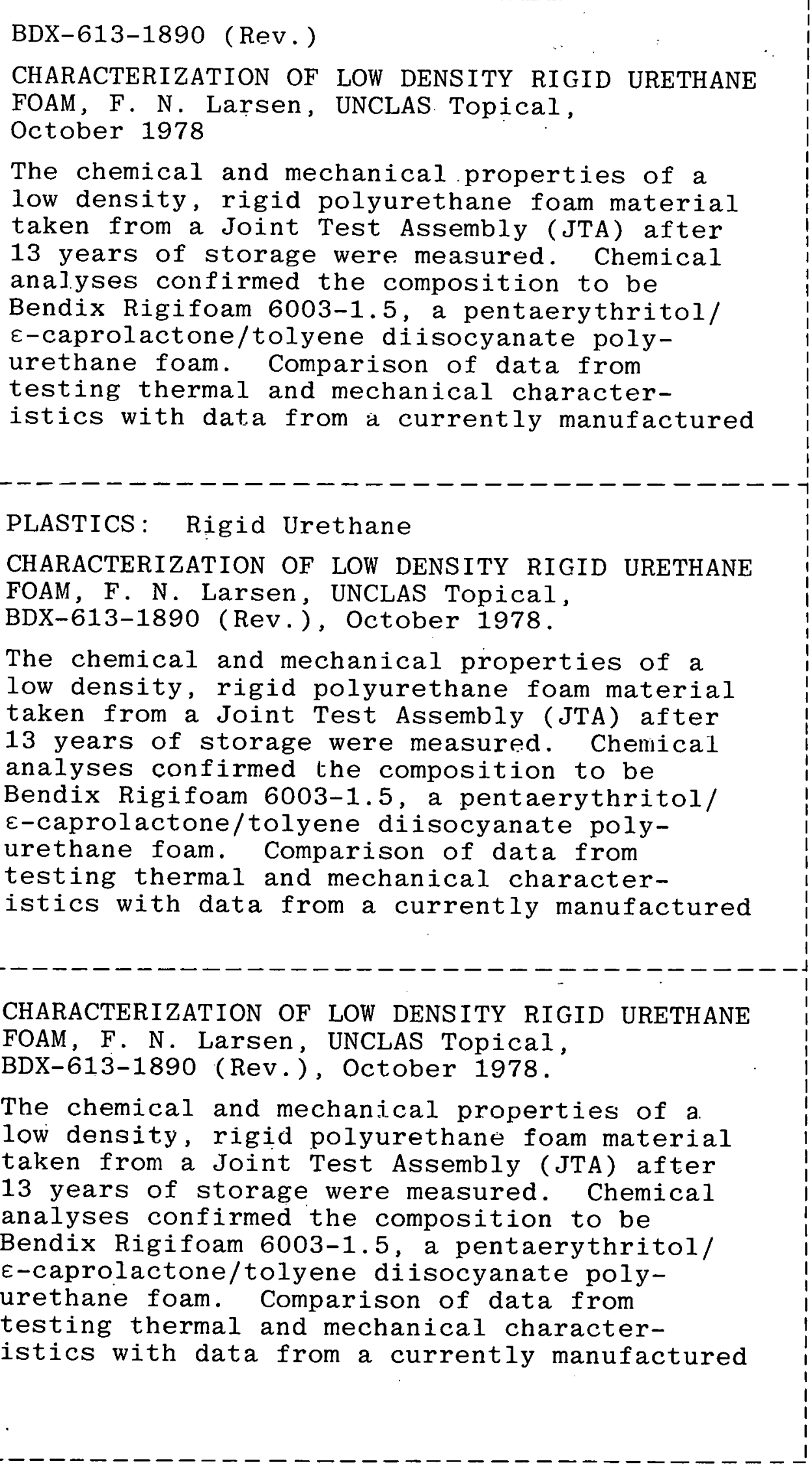


foam of identical composition indicates no degradation of properties had occurred. This information gives added confidence to the stockpile lifetime integrity of the Rigifoam 6003-2 foam system designated for use in other programs.

foam of identical composition indicates no degradation of properties had occurred. This information gives added confidence to the stockpile lifetime integrity of the Rigifoam 6003-2 foam system designated for use in other programs.

foam of identical composition indicates no degradation of properties had occurred. This information gives added confidence to the stockpile lifetime integrity of the Rigifoam 6003-2 foam system designated for use in other programs. 